\title{
The structural factor of regional economic stability in Russia during the coronacrisis period
}

\author{
O.A. Romanova $\bowtie$, A.O. Ponomareva \\ Institute of Economics of the Ural Branch of the Russian Academy of Science, Ekaterinburg, Russia; romanova.oa@uiec.ru
}

\begin{abstract}
Relevance. The coronavirus pandemic has lead to one of the most serious crises in the global economy. The significant disparities between Russian regions influenced the levels of morbidity and their strategies of containing the crisis.

Research objective. The aim of this paper is to identify the factors of regional development which, during the pandemic and in the post-pandemic period, affected and will affect the economic stability of Russian regions.

Materials and Methods. The research is based on the Rosstat data, industry reviews, materials from analytical and consulting firms, Russian and international research literature. The research methodology is based on the structuralist approach and the provisions of the new structural economics put forward by J. Lin. The methods of comparative, statistical, and structural analysis were also used.

Results. The most significant factors in regional economic development are the structure of the economy and the quality of public administration at the national and regional levels. The high-tech sector in the structure of a regional economy plays a pivotal role in ensuring its stability in the times of crisis. The study shows the need for a transition to independent national value chains. It is also necessary to develop a long-term national strategy aimed at stimulating the structural transformation of regional economies.

Conclusions. The study has demonstrated the importance of the two key factors in shaping the regions' responses to the pandemic and the speed of their recovery - the structure of regional economy and the role of the government. These factors should be taken into account by the Strategy of the State Regional Industrial Policy.
\end{abstract}

\section{KEYWORDS}

economic structure, factors of territorial development, economic sustainability, coronavirus, hightech manufacturing, value chain, regional industrial policy

\section{ACKNOWLEDGEMENTS}

The paper was prepared within the framework of the state assignment of the Ministry of Science and Higher Education of the Russian Federation for Federal State Budgetary Institution of Science "Institute of Economics" of the Ural Branch of the Russian Academy of Sciences for 2021.

\section{FOR CITATION}

Romanova, O.A., Ponomareva, A.O. (2021). The structural factor of regional economic stability in Russia during the coronacrisis period. R-economy, 7(3), 158-169. doi: 10.15826/recon.2021.7.3.014

\section{Структурный вектор повышения экономической устойчивости региона в период коронакризиса}

\author{
О.А. Романова $\bowtie$, А.О. Пономарёва \\ Институт экономики Уральского отделения Российской академии наук, Екатеринбург, Россия; \\ romanova.oa@uiec.ru
}

\begin{abstract}
АННОТАЦИЯ
Актуальность. Пандемия коронавируса спровоцировала один из самых сложных и глубоких кризисов мировой экономики. Высокий уровень дифференциации субъектов РФ по последствиям его влияния на глубину экономического спада, на уровень заболеваемости населения, предопределяет актуальность выявления факторов, оказавшихся наиболее значимыми в кризисный период.

Цель исследования. Целью статьи является выявление факторов регионального развития, которые в условиях коронакризиса и в постпандемийный период определяющим образом будут влиять на экономическую устойчивость регионов России.

Данные и методы. Основой исследования явились данные Росстата, отраслевые обзоры, материалы аналитических и консалтинговых фирм, работы отечественных и зарубежных специалистов в области предварительной оценки последствий влияния кризиса на мировую, отечественную и региональную экономику. Методология исследования основана на структура-
\end{abstract}

\section{КЛЮЧЕВЫЕ СЛОВА}

структура экономики, факторы территориального развития, экономическая устойчивость, коронакризис, высокотехнологичное производство, цепочка создания ценностей, региональная промышленная политика 
листком подходе, на использовании положений новой структурной экономики Дж. Линя. Использованы методы компаративного, статистического и структурного анализа.

Результаты. Установлено, что наиболее значимыми факторами развития региональной экономики являются структура экономики и качество государственного управления на национальном и региональном уровнях. Рассмотрена роль высокотехнологичного производства в структуре экономики как фактора повышения ее устойчивости. Показана необходимость перехода к независимым национальным цепочкам создания ценности, что повышает возможность их локализации и значимость региональных участников. Обоснована значимость государственной региональной промышленной политики как системы мер, формирующих долгосрочную стратегию структурной трансформации экономики.

Выводы. Подтверждена правомерность выделения структуры экономики и возрастающей роли государства в экономической жизни общества как важнейших факторов, влияющих на экономическую устойчивость региона и скорость его выхода из кризиса. Обоснована необходимость учета данных факторов в рамках Стратегии государственной региональной промышленной политики, реализующей структурный вектор развития региональной экономики.

\section{БЛАГОДАРНОСТИ}

Статья подготовлена в соответствии с планом НИР для ФГБУН Институт экономики УрО РАН на 2021 год

\section{ДЛЯ ЦИТИРОВАНИЯ}

Romanova, O.A., Ponomareva, A.O. (2021). The structural factor of regional economic stability in Russia during the coronacrisis period. R-economy, 7(3), 158-169. doi: 10.15826/recon.2021.7.3.014

\section{Introduction}

The COVID-19 pandemic has caused a severe global crisis, which is fundamentally different from all previous crises. It is not economic in nature, since it was determined not by socio-economic factors but by the factors of an exogenous, in this case biological, nature. The planetary scale of the crisis had a devastating effect on the world economy as a whole, on the economy of all national states, on all industries and spheres of economic activity without exception. The COVID Action Platform was created at the World Economic Forum in Davos, stating: "The dramatic spread of COVID-19 has disrupted lives, livelihoods, communities and businesses worldwide" ${ }^{\text {. }}$

The above-described circumstances prevented national governments from resorting to standard anti-crisis measures. In addition, the significant disparities between the countries (the level of socio-economic development, the structure of the economy, the volume and quality of public services) resulted in the differences in the anti-crisis measures taken by each state. The effectiveness of the measures also depended on the governments' competence and their capacity for efficient decision-making in this situation. A special role in such conditions was played by the public attitudes, opinions and beliefs, which shaped people's responses to restrictive measures. The combination of all these factors had a decisive influence on the depth of the econo-

1 The COVID Action Platform. Davos, the World Economic Forum. 2020. URL: https://www.weforum.org/platforms/covid-action-platform (accessed 28.06.2021). mic recession in individual countries, on the possibility of maintaining economic stability.

Russia has demonstrated a relatively high level of resilience to the coronavirus crisis. The rate of decline in GDP was 3.0\% in Russia; in Germany, 4.8\%; in France, 8.0\%; Italy, 8.9\%, and in the UK, $9.8 \%{ }^{2}$. In general, the rate of decline in Russia's GDP in 2020 turned out to be almost 2\% lower than the average level for all G20 countries.

The system of anti-crisis measures taken in almost all countries helped to some extent to mitigate the consequences of the negative shocks. However, in order to increase the effectiveness of these measures in the face of the new waves of COVID-19, coordinated efforts are needed not only by the governments of different countries but also of regional authorities within each country.

In the light of the different socio-economic consequences of the pandemic faced by Russian regions, it is necessary to identify the factors that are the most significant for maintaining economic stability. The economic stability of a region as a socio-economic system in this context is understood as its ability to maintain a certain level of performance despite the negative changes in the external environment. The aim of the study is to identify the factors of regional development, which, during the pandemic and in the post-pan-

${ }^{2}$ World Economic Outlook Database, April / International Monetary Fund. 2021. URL: https://www.imf.org/ en/Publications/WE0/weo-database/2021/April/ (accessed: 15.07.2021); World Economic Outlook, October / International Monetary Fund, 2019. URL: https://www.imf.org/en/ Publications/WEO/weo-database/2019/October/ (accessed: 15.07.2021). 
demic period, will decisively affect the economic stability of Russian regions. This research objective determines the following goals:

- to systematize and analyze Russian and international research on the factors of regional development;

- to identify the characteristics of regional economies and the most significant factors of their development in the pandemic;

- to show the importance of high-tech and value chains as structural factors of regional economy;

- to demonstrate the growing importance of government regulation in the economy and to show the role of regional industrial policies in balanced development of regional economies.

Despite the existing research literature on the consequences of the crisis (Seliverstov et al., 2021; Polidi and Gershovich, 2021; Kuznetsova, 2020; Miles et al., 2021), the topic of the structural characteristics of regional economies that determined their responses to the crisis still remains largely underexplored.

\section{Conceptual framework and methodology}

There is a body of research seeking to systematize and analyze the factors of regional development (see, for example, Zubarevich, 2010; Melnikov, 2007; Kuznetsova, 2014; Yakishin, 2019; Rodrik, 2003; Rodrik, 2013). The studies of the World Bank are widely known, where the three key factors of territorial development have been identified - density, distance, and division ${ }^{3}$. The interpretation by Zubarevich of the latter term as "institutional barriers" seems important for this study (Zubarevich, 2020). Equally wellknown are the two groups of factors identified by Krugman: "first nature causes", which include resource availability and geographic location, and "second nature causes", including the agglomeration effect, institutional environment, and human capital (Krugman, 1991). These factors, according to Krugman, depend on the activities of the state and society.

A somewhat different approach to the typology of factors of regional development was proposed by Rodrik, who distinguishes between "direct" and "deep" factors (Rodrik, 2003). The former include endogenous factors of production - productivity and accumulation of physical

\footnotetext{
${ }^{3}$ World Development Report (2009). Reshaping Economic Geography. The World Bank. Washington.
}

and human capital. The deep factors are interpreted as exogenous and include institutions, geography, and foreign trade. The approach to the systematization of factors of regional development proposed by Kuznetsova is different. Her hierarchical five-level model developed is presented in the form of a pyramid of factors (Kuznetsova, 2014). At the bottom, there are three levels comprising the basic factors: resources and natural and climatic conditions, settlement patterns and demographic characteristics, infrastructure availability. The fourth level characterizes the level of development and structure of the regional economy, and the highest fifth level includes subjective factors, including primarily the socio-economic policy of the state. Importantly, the structure of the economy as considered as an independent factor influencing regional socio-economic development. The importance of this factor was substantiated in detail by Lin, who proposed the theory of the new structural economics (Lin, 2011).

The importance of institutional factors was emphasized in the above-mentioned works by Krugman, Rodrik, and in the studies of the World Bank. The socio-economic disparities between Russian regions was pointed out by Kuznetsova in her analysis of the general spectrum of institutional factors. In the pyramid she puts this factor at the highest, fifth level. It means that the policy pursued by the federal center in relation to the regions. This policy is the factor which can contribute to the development of regions even in the situations of crisis. The general policy set by the federal government should be turned into regionallevel policies taking into account the specific characteristics and needs of the regions.

The structure of regional economies and regional policies are the key factors that determine regions' responses to the crisis and the speed of their recovery. This conclusion is confirmed by the idea of Keynes about the crucial role of the state in national economic development (Keynes, 1998, 2000). His idea of the priority of budgetary rather than monetary policy in economic regulation rings especially true in the reality of the pandemic. The following principles of state regulation developed by Perroux are also relevant in the modern world: the selective impact on economy; the possibility of uneven growth, and the active transformation of the sectoral structure (Perroux 1961)). These areas which form the basis of modern structural (industrial) policy should be 
used in full measure when adjusting regional economic policies to meet the challenges of the postCOVID-19 era.

The research literature highlights the main factors that can help countries fight the pandemic and ensure a fast recovery in the post-pandemic period. According to Seliverstov et al. (2011), these include the following:

- the quality of public administration at the national and regional levels;

- the development of $\mathrm{R} \& \mathrm{D}$, in particular in the pharmaceutical sphere, to create vaccines and drugs;

- the development of the high-tech sector, including the pharmaceutical industry;

- people's willingness to adhere to the restrictive measures (Seliverstov et al., 2011).

Several other factors that determine regional economic development during the pandemic are identified by Nikolaev et al. (2021):

- epidemiological situation;

- readiness and efficiency of the healthcare system;

- structural features of the economy;

- effectiveness of the anti-crisis policy.

Thus, the research literature describes numerous factors that affect the development of regions and determine the gravity of economic recession. In addition to the level and quality of regional healthcare systems, the availability of high-tech, primarily pharmaceutical production, both Russian and international experts pointed out the structural features of the economy as well as the quality and efficiency of the public administration system. These factors, as shown by the theoretical review, are the most significant for economic growth and the development of the regional economy as a whole.

Due to the lack of information on the socio-economic situation in the regions during the pandemic, we chose the methods of comparative and structural analysis and the method of dynamic statistical analysis. Statistical methods are used to analyze the structure of the regional economy and its development. The study uses such well-established methods as the classification of Russian regions according to the prevalence of specific types of activity in the structure of their economies. To identify the factors that have a significant impact on regional economy and determine both the depth of the economic crisis and the possibility of faster recovery, the method of systematic literature review was applied.

\section{Results}

As we have discussed above, although the economic aspects of the COVID-19 pandemic in Russia were analyzed in research literature (Kuznetsova, 2020; Mau et al., 2020; Nigmatulin et al., 2020), the regional aspect is still underexplored.

\section{Structure of regional economies}

Russian regions vary significantly in terms of their socio-economic development, specialization, and the COVID-19 incidence rates (Zubarevich, 2020b). An analysis of the available statistics showed that the industrial specialization of regions and cities, that is, the structural factor, had a significant impact. The structure of the economy both on the national and regional level had a decisive impact on how hard countries and regions were hit by the pandemic. At the same time, the structure of the Russian economy, not optimal by world standards, played a positive role in the second, most dramatic, quarter of 2020 and Russia had lower rates of economic decline in comparison with the USA, France, Germany, the UK, and Japan. Russia's GDP decreased by $8 \%$ compared to the same period in 2019 while in the UK, by $21.7 \%$, in France, by $19 \%$, in Italy, by $17.3 \%$, and in Germany, by $11.7 \%$ (Nikolaev et al., 2021). It should be noted that the share of gross value added (GVA) of the industry in total GVA of the Russian economy during this period was $25.1 \%$, while in the UK it was $12.2 \%$, in France, $12.3 \%$, and in Italy, $17.6 \%$. Only in Germany, this figure $(21.6 \%)$ is comparable to Russia (Nikolaev et al., 2021).

However, other structural components of the German economy differ significantly from the structure of the Russian economy. In Germany, the share of the service sector in GVA is about $70 \%$, and in Russia 60\% (Kuznetsova, 2020). It should be noted that in Russia, the share of simple services in the total volume of services, in particular, trade, is 1.4 times higher than in Germany. However, in Germany, the share of complex services, such as ICT, professional, scientific, and engineering activities, healthcare and social services is higher than in the sectoral structure of the Russian economy (share of GVA) by 1.9, 1.4, and 2.3 times, respectively.

We believe that the Russian economy enjoyed greater advantages during the lockdown period in comparison with its Western counterparts for the following reasons: GVA of the industry accounts for a larger share in the country's total GVA and less restrictions were imposed on the industrial 
sector, moreover, a relatively low share of services was subjected to harsh restrictions. The same factors determine the differences in the structure of GRP and economic stability in Russian regions. Significant structural components of regional economies include the share of manufacturing and wholesale and retail trade in the GRP structure. According to these two parameters, we can identify two groups of regions - industrial regions (with the share of manufacturing over 27\%) and regions where the total share of services is more than $31 \%$, and the share of trade in their GRP exceeds $17 \%$ - regions reliant on trade and services (Fig. 1, 2).

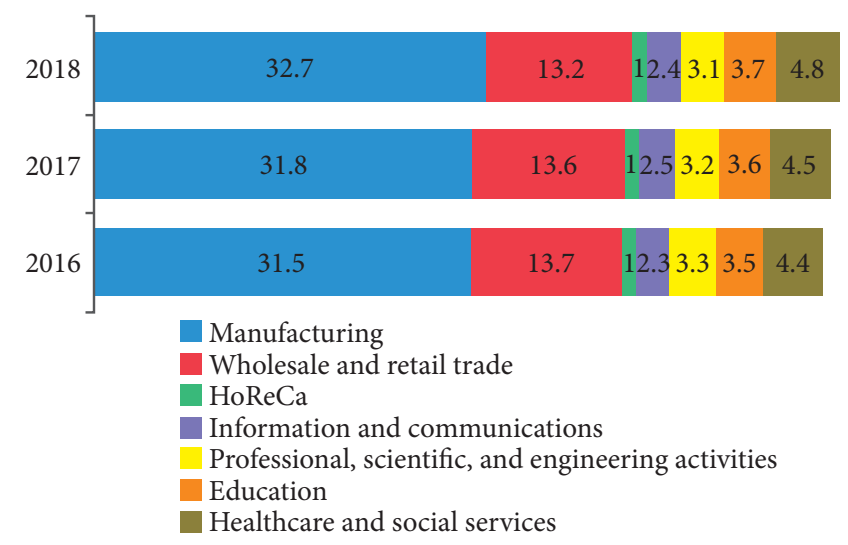

Figure 1. Change in the structure of GRP in industrial regions, \%

Source: the authors' calculations are based on "Regions of Russia. Main Characteristics of the Constituent Entities of the Russian Federation 2020". Retrieved from: https://rosstat.gov.ru/folder/210/document/13205

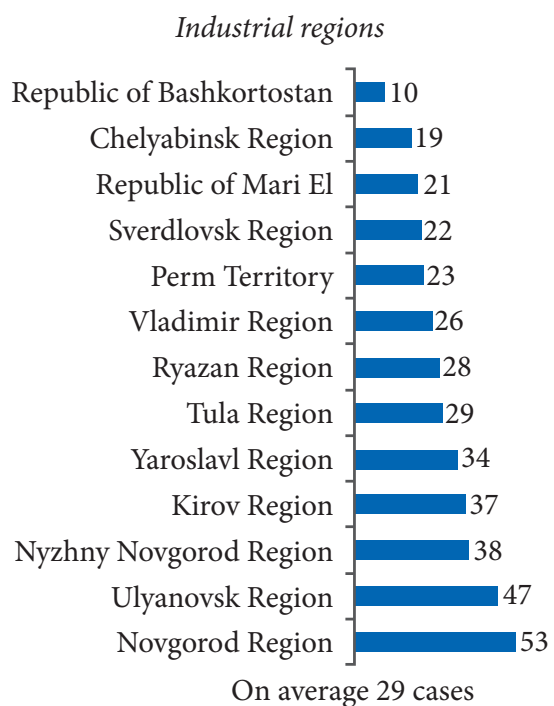

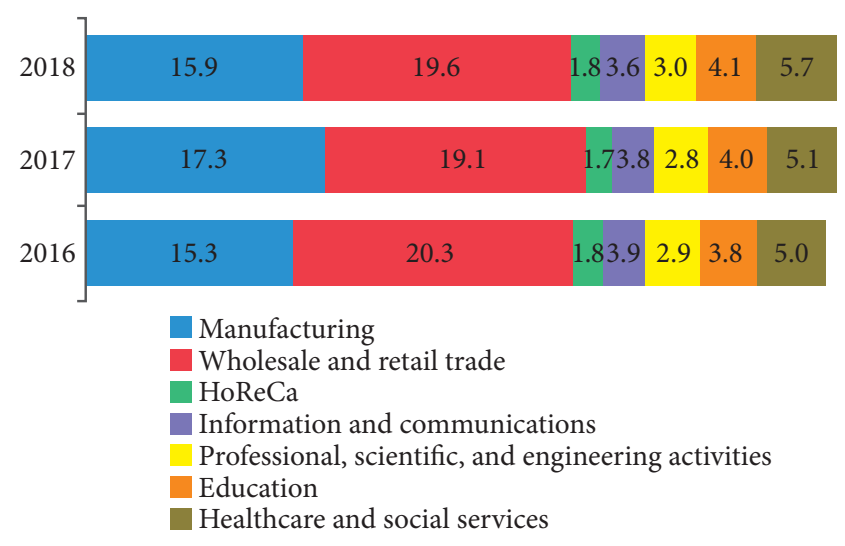

Figure 2. Change in the structure of GRP in Russian regions reliant on trade and services, \% Source: the authors' calculations are based on "Regions of Russia. Main Characteristics of the Constituent Entities of the Russian Federation 2020". Retrieved from: https://rosstat.gov.ru/folder/210/document/13205

An insignificant change in the structure of GRP for the two groups of Russian regions in 2016-2018 (Fig. 1, 2) shows that there have been no serious changes in the structure of regional economies. Fig. 3 shows the groups of regions depending on their incidence rates and specialization (industrial regions or regions reliant on the service sector).

The average number of detected cases of the coronavirus infection in regions reliant on the service sector is 1.4 times higher than in industrial regions. Thus, the former were hit the hardest by the pandemic.

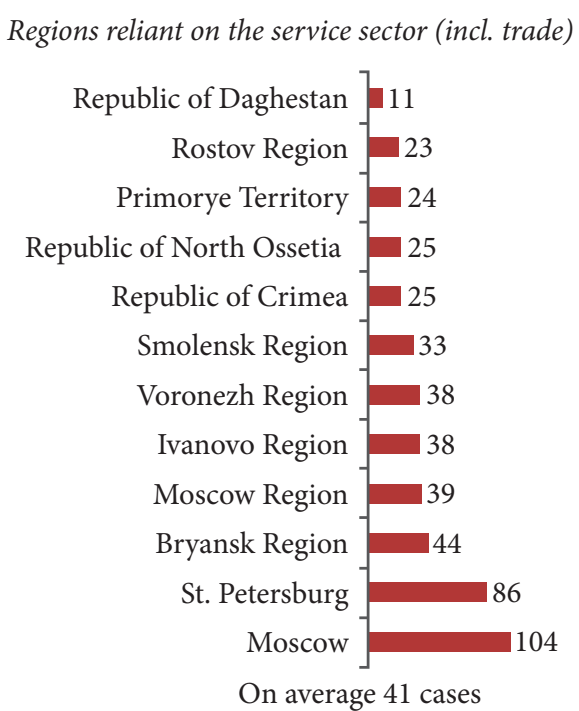

Figure 3. The number of detected cases of the coronavirus infection in Russian regions as of June 2021, cases/1,000 people

Source: the authors' calculations are based on COVID-19 statistics in Russia. The cumulative total as of June 26, 2021. Retrieved from: https://coronavirus-monitor.info/country/russia/ (accessed 26.06.2021) 


\section{Economic structure of urban agglomerations}

The structure of regional economies in Russia partially depend on the structure of the largest urban agglomerations located in these territories. An analysis of changes in the gross urban product (GUP) for 17 million-plus urban agglomerations at the end of 2020 showed that in most of them, the economic losses did not exceed the national average (Polidi et al., 2021). The decline in Russia's GDP in 2020 was $3.1 \%$, which exceeds the decline in real GUP (within 3\%) in such major agglomerations as Chelyabinsk, Ufa, Samara-Tolyatti, Perm, and Yekaterinburg. For six agglomerations, this decrease was less than $1 \%$; for five, less than $2 \%$; and one agglomeration (Krasnodar) showed an increase in real GUP by $2 \%$.

Let us look at the structure of the economy of the four largest industrial cities, by the number of people employed in the most important spheres of the service sector (Table 1).

The largest share of employees in healthcare and social services (18\%) at the end of 2020 was observed in Chelyabinsk. Interestingly, in comparison with other industrial regions, Chelyabinsk region had the smallest number of cases (Fig. 3).

The dynamics of the average number of employees for the most popular types of services in the current period is also worthy of interest (see Fig. 4).

Yekaterinburg has the largest number of employees in wholesale and retail trade and Chelyabinsk, the smallest. At the same time, the growth in the number of employees in this area from 2017 to the first quarter of 2021 was the largest in comparison with the change in employment for all the cities and types of services. Leaders in the field of

Structure of employment by types of services in the largest industrial cities in 2020, \%

Table 1

\begin{tabular}{|l|c|c|c|c|c|c|c|c|}
\hline \multicolumn{1}{|c|}{ Indicators } & \multicolumn{2}{|c|}{ Yekaterinburg } & \multicolumn{2}{c|}{ Chelyabinsk } & \multicolumn{2}{c|}{ Nizhny Novgorod } & \multicolumn{2}{c|}{ Novosibirsk } \\
\cline { 2 - 9 } & Total & $\mathbf{\%}$ & Total & $\mathbf{\%}$ & Total & $\mathbf{\%}$ & Total & $\mathbf{\%}$ \\
\hline Population by types of services, people & 342,837 & $100 \%$ & 209,845 & $100 \%$ & 293,263 & $100 \%$ & 315,533 & $100 \%$ \\
\hline $\begin{array}{l}\text { Including: } \\
\text { Wholesale and retail trade }\end{array}$ & & & & & & & \\
\hline ICT & 64,594 & $19 \%$ & 27,814 & $13 \%$ & 44,734 & $15 \%$ & 44,660 & $14 \%$ \\
\hline $\begin{array}{l}\text { Professional, scientific, and engineering } \\
\text { activities }\end{array}$ & 20,311 & $6 \%$ & 8,046 & $4 \%$ & 22,789 & $8 \%$ & 17,697 & $6 \%$ \\
\hline Healthcare and social services & 24,55 & $7 \%$ & 4,964 & $2 \%$ & 26,396 & $9 \%$ & 27,622 & $9 \%$ \\
\hline
\end{tabular}

Source: the authors' calculations are based on the database "Indicators of Municipalities". Retrieved from: https://gks.ru/dbscripts/munst/munst.htm

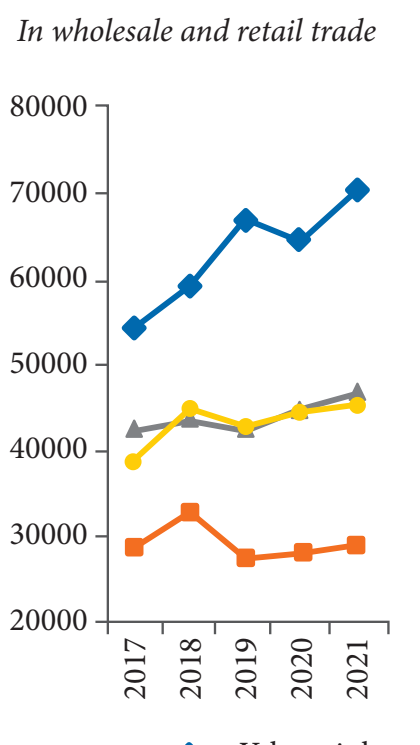

In healthcare and social services

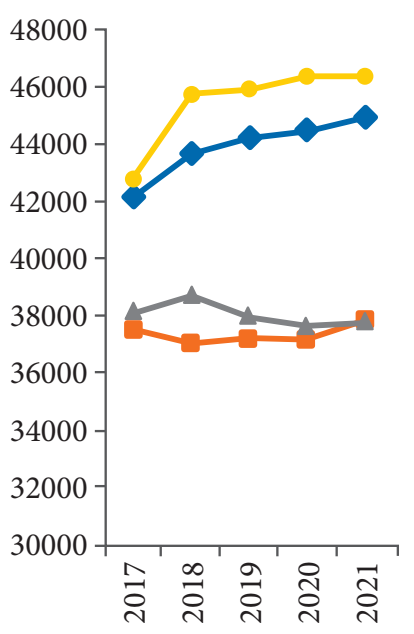

-Chelyabinsk

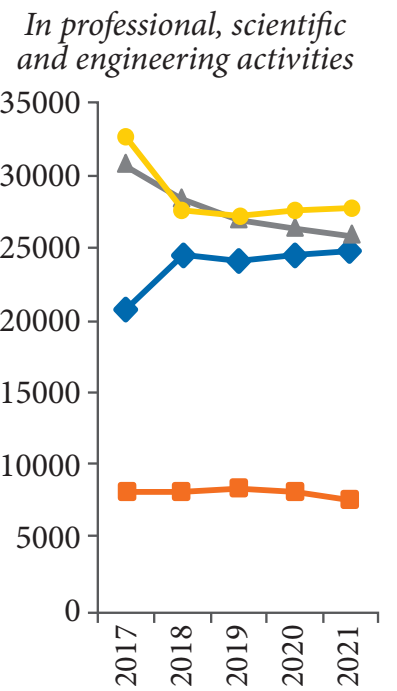

$\longrightarrow$ Nizhny Novgorod
In ICT

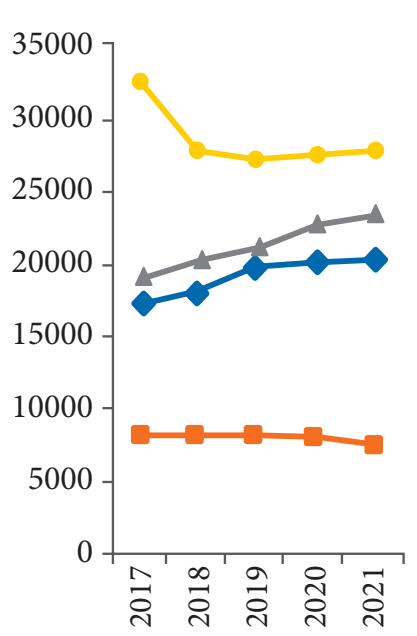

Figure 4. Dynamics of the average number of employees by types of services, people Source: the authors' calculations are based on the database "Indicators of Municipalities".

Retrieved from: https://gks.ru/dbscripts/munst/munst.htm 
such complex services as professional, scientific, engineering activities and ICT are Novosibirsk, Nizhny Novgorod, and Yekaterinburg. Novosibirsk and Yekaterinburg are also the leaders in the sphere of medical and social services. The only city where there was a decrease in the number of healthcare employees is Nizhny Novgorod. This city also saw a decrease in the number of people employed in professional, scientific, and engineering activities, but, unlike other cities, the number of employees in ICT is increasing.

It is also important to look at the COVID-19 statistics and the restriction measures implemented in the regions where the above-mentioned cities are the administrative and economic centers (Table 2).

COVID-19 statistics and restriction levels

Table 2 in Russian regions

\begin{tabular}{|l|c|c|}
\hline \multicolumn{1}{|c|}{ Regions } & $\begin{array}{c}\text { Restriction } \\
\text { levels* }\end{array}$ & $\begin{array}{c}\text { Number of cases per } \\
\text { 100 thousand people } \\
\text { as of June 2021 }\end{array}$ \\
\hline Novosibirsk region & Severe & 1,679 \\
\hline Chelyabinsk region & Very severe & 1,860 \\
\hline Sverdlovsk region & Moderate & 2,173 \\
\hline $\begin{array}{l}\text { Nizhny Novgorod } \\
\text { region }\end{array}$ & Mild & 3,859 \\
\hline
\end{tabular}

Note: * The level of restrictions is determined by the number of suspended activities. Source: Foundation "Institute for Urban Economics". Differentiation of regions in terms of the severity of restrictive measures in the pandemic. Moscow. 2020. Retrieved from: http://www.urbaneconomics.ru/ centr-obshchestvennyh-svyazey/news/differenciaciya-regionov-po-zhestkostiogranichitelnyh-mer-v

Source: the authors' calculations are based on the COVID-19 statistics in Russia. The cumulative total as of June 26, 2021. Retrieved from: https://coronavirus-monitor.info/ country/russia/ (accessed 26.06.2021)

We believe that only a qualitative assessment of the relationship between the structure of the economy, the level of restrictions, and the number of cases is possible. However, interestingly enough, in Novosibirsk region, where the restrictions were rather rigorous, the number of cases per 100 thousand people as compared to other regions was minimal, while in Nizhny Novgorod region the restrictions were milder but also the number of cases was higher. In Sverdlovsk region, which has the highest number of employees in wholesale and retail trade, the restrictions were moderate and this could have contributed to the high level of morbidity. Thus, in large urban agglomerations, the prevalence of the share of services in the structure of the economy is one of the factors affecting these cities' vulnerability during the pandemic.

\section{The role of the high-tech sector in the economic stability of regions}

The pandemic has increased the importance of the high-tech sector and R\&D both in overcoming the crisis and solving he current problems of socio-economic development. The term "transformational research" reflects the global trends of prioritizing exploratory research focused on practical results. Transformational research is understood as the process which re-orients fundamental research towards solving practical goals dealing with the transformation of the socio-economic system (Dezhina et al., 2020). A special role in such research in Russia can be played by medium-sized, mainly private, technology companies, which demonstrate not only high growth rates and labor productivity but also spend a lot on R\&D (9-14\% of their revenue) (Dezhina et al., 2020). The operation of these companies and their support by regional authorities can contribute to progressive structural changes in the economy of the regions where these business structures are located. Today they are not the main beneficiaries of the government's investments in $R \& D$, but this situation may change.

Policy-making aimed at ensuring long-term structural transformations in Russian regions and in the country as a whole should prioritize the development of the IT sector and an increase in the share of high-tech services in all sectors of the economy. There is evidence that companies that remain innovative during crises gain significant advantages over their competitors during the period of economic recovery (Bar, 2020).

The analysis of the problems faced by Russian enterprises in the high-tech sector in connection with the COVID-19 pandemic carried out by the Institute for Statistical Studies and Economics of Knowledge (ISSEK) of the Higher School of Economics (Vlasova, 2021) shows that the most affected type of innovative activity was scientific and industrial cooperation. About half of the high-tech industrial enterprises have reduced or completely stopped interactions with Russian universities and research organizations (Simachev, 2021). Interactions with other counterparties have also significantly decreased. At the same time, over $80 \%$ of high-tech companies announced that they expected to intensify and improve their production processes in 2021. Almost two-thirds of enterprises in the high-tech sectors are planning to innovate and intensify their own $\mathrm{R} \& \mathrm{D}$. However, less than a half of the companies (47\%) are planning to establish new partnerships 
with research organizations and universities. In these conditions, it becomes problematic to conduct "transformational research" aimed at transforming, primarily in the structural aspect, regional socio-economic systems.

\section{Value chains during the coronacrisis}

The coronavirus pandemic has raised structural problems not only in regional and municipal economies; it also exacerbated the problems related to value chains. Due to the strong interconnections between the industries and the length of these chains, they were especially vulnerable to pandemic shocks: there were some serious disruptions in value chains and in supply chains. In this regard, an urgent task to be addressed is to help the chains adapt to the crises of the world economy and to get a better understanding of the role played by regional participants (2020; Varnavsky, 2021) ${ }^{4}$.

The limitations of globalization associated with the increasing political and economic risks and the growing share of services in developed and developing countries reduce the importance of cooperative supplies and value chains, the latter being needed more in the production of goods, rather than services. In addition, the length of production chains tends to decrease as production sites are getting closer to end-users.

Thus, in the changing world, a new approach to assessing the efficiency of production location is gaining currency as independent national supply chains are strengthened and the significance of regional participants is growing. The real transformation of value chains creates incentives not only for business entities and regional authorities but also for governments to develop possible options for the creation of more stable structures. Regionalization of chains can increase the stability of value chains and their adaptability to various kinds of shocks. In turn, the localization of value chains will help to increase the resilience of regional economies to external risks, making them more dynamic and responsive to the constantly changing consumer preferences.

\section{Regional economic policy}

The coronavirus pandemic has resulted in a tremendous increase in the importance of digital technologies and stimulated digital transformation in various sectors of economy. However,

${ }^{4}$ COVID Action Platform (2020). Davos, World Economic Forum. Retrieved from: https://www.weforum.org/platforms/covid-action-platform (accessed 12.10.2020). it also exacerbated regional disparities. All of the above increases the importance of the role played by the government in the national economy (Romanova, 2020). In addition, the extreme polarization of socio-economic development in Russian regions complicated the situation for the regional governments struggling to ensure the sustainable development of their territories.

Center and regions. At the federal level, in April-May 2020, the Russian government developed three packages of measures to combat the pandemic, which also included measures to support the economy and people. The first package of measures was aimed to provide significant support for SMEs (halving the rates of social insurance payments, credit holidays); it also included a program of preferential loans for paying wages, and financial support for affected industries. The total volume of this package was $0.3-0.4 \%$ of GDP. The second package of measures, which included some support for regional budgets, strategic enterprises, and additional payments to healthcare staff, amounted to about 1\% of GDP. A specific feature of the third and largest package was direct payments to the population. However, according to a number of experts, the volume of resources allocated for combatting the pandemic in Russia was clearly insufficient, because the National Wealth Fund and the country's foreign exchange reserves made it possible to strengthen support for both the people and business (Aganbegyan, 2020).

The alarming situation resulting from the rapid spread of the coronavirus caused serious changes in the distribution of powers between the center and the regions. Since April 2020, in accordance with the Decree of the President of the Russian Federation No. 239, regional governors have been made responsible for the development and implementation of measures aimed at ensuring public health and combating the coronacrisis as well as maintaining economic activity ${ }^{5}$. Despite the obvious expediency of such solution, in Russian regions, it created serious economic problems, because the regional authorities applied measures to combat the pandemic based not so much on the significance of the problems but the availability of

Decree of the President of the Russian Federation of April 2020 No. 239 "On measures to ensure the sanitary and epidemiological well-being of the population in the territory of the Russian Federation in connection with the spread of the new coronavirus infection (COVID-19)". Retrieved from: http:// www.consultant.ru/document/cons doc LAW 349217/ (accessed: 22.06.2021). 
resources. Since Russia, unlike many other countries, did not declare a state of emergency in the country as a whole, the regions made independent decisions on the introduction of various restriction options. Forty-five regions introduced a high alert, the rest, depending on their incidence rates, introduced restrictions of other levels ${ }^{6}$.

The introduction of restrictive measures by regional governments has gradually reduced the number of cases. However, at the same time, there was a sharp decline in demand and in the income of households, the activity of a significant part of the service sector all but ceased, and so on. In order to support business, all 85 Russian regions introduced various economic measures: tax incentives, postponement or reduction of rental rates for small businesses as well as for the most affected industries. In total, 839 economic measures were used in the regions, $45 \%$ of which were tax and 55\% non-tax (Seliverstov et al., 2021).

The consequences of the transfer of the responsibility for combating the pandemic to regional governments led to a significant increase in their expenditures. More than a half of Russian regions are experiencing an increase in their budget deficit. The discrepancies between the responsibility of regional authorities and the real resources they have at their disposal have grown significantly.

The opinion of a group of Russian experts about the changes in the sustem of regional government during the pandemic was best summarized by Pertsev, who described the asymmetrical 'center-regions' relationship as 'a vertical with no obligations that works mainly in one direction - [the centre] takes a lot but gives little in return' (Pertsev, 2020). At the same time, it seems reasonable to decentralize decision-making to combat the coronavirus, to transfer responsibility and authority to the regional level, which helped to reduce the rate of the COVID-19 spread nationwide.

\section{Regional industrial policy}

The importance of the regional industrial policy during the pandemic is increasing not only because it is a tool that helps solve the current economic tasks but mainly because it is a tool for building a long-term policy of structural transformations in line with the modern technological trends (Romanova, 2018a; Romanova,

${ }^{6}$ Information on the introduction of passes or restrictions on movement in the regions (some municipalities) of the Russian Federation based on the regulations published as of July 15, 2020. Retrieved from: http://base.garant.ru/77398959/ (accessed: 20.06.2021). 2018b; Tambovtsev, 2017). More attention is now paid to the development of strategic rather than tactical measures to ensure the long-term sustainability of economic development, increase the resilience of SMEs and other types of enterprises. The governments of 33 developed and developing countries implemented measures to support the digitalization of their economies, and the government of 30 countries supported innovation in the manufacturing and service sectors (Gafurova and Kovaleva, 2021).

The most important goal of a regional industrial policy in the modern period is not only ensure economic stability but also to build a strategy for the economy's structural transformation. The development of interregional cooperation, the use of opportunities for horizontal cooperation between regional authorities should find an important place in such a strategy (Turgel and Usoltseva, 2020). The institution of the plenipotentiaries of the President in federal districts mostly worked as a control body, which, of course, is an important function in the times of crisis. As for the organizational functions, however, the plenipotentiaries' performance left much to be desired, especially in terms of their contribution to the development of horizontal cooperation, mobilization of the regions' resources, which were extremely limited, and joint action to combat the pandemic.

An important task is to ensure the balance of these functions because the already existing interregional socio-economic disparities together with the possibilities of attracting highly qualified personnel can lead in the post-pandemic period to an even greater inequality of regions, primarily to digital inequality. Therefore, in regional strategies, an important place should be given to priorities related to the digitalization of the real and service sectors. It is also important to invest in the development of ICT and in medical and pharmaceutical research.

\section{Conclusion}

The study identifies two factors that affect the economic stability of regions and the speed of their recovery from the crisis - the structure of the economy and the increasing role of the state in the economy. The combination of these two factors makes regional socio-economic systems more stable in the face of the pandemic shocks, that is, an optimal balance is maintained between the level of economic activity in regions and public health protection. Other tasks include diversi- 
fication of the economy, maintaining and developing the industrial potential; and optimization of the service sector.

A special role in this process is played by the government's industrial policy. Its implementation is regulated by the Federal Act "On Industrial Policy in the Russian Federation". However, this regulation does not actually take into account the territorial factor, which was the reason for the development of the "Strategy for the Regional Industrial Policy of the Russian Federation until 2024 and for the Period until 2035" by the Min-

${ }^{7}$ Draft Strategy for the regional industrial policy of the Russian Federation until 2024 and for the period until 2035. Retrieved from: https://minpromtorg.gov.ru/docs/\#!strategiya regionalnoy promyshlennoy politiki rossiyskoy federacii do 2024 goda $i$ na period do 2035 goda (accessed: 20.06.2021). istry of Industry and Trade of Russia. The draft Strategy describes measures for targeted support of individual regions and macro-regions, taking into account not only their industrial specialization but also the interests of national security. Importantly, the Strategy highlights the need for advanced industrial development of struggling regions. The priority is to build value chains by strengthening industrial cooperation and by localizing value chains within Russia. The implementation of the Strategy can help not only increase the economic stability of regions, but also stimulate the struggling regions to make the most of their resources, to benefit from interregional cooperation, primarily within their federal districts, and receive real support from the federal center.

\section{References}

Aganbegyan, A.G. (2020). On the need for a new socio-economic policy. Central Russian Journal of Social Sciences, 15(3), 5-15. doi: 10.22394/2071-2367-2020-15-3-15-50

Varnavsky, V. (2021). Global value chains during the COVID-19 pandemic. World Economy and International Relations, 65(1), 14-23. doi: 10.20542/0131-2227-2021-65-1-14-23

Vlasova, V., \& Rud, V. (2021). Effects of the COVID-19 pandemic on innovation in Russian high-tech. Express information from ISSEK of the NRU HSE. Retrieved from: https://issek.hse.ru/ news/473020936.html

Gafurova, G.T., \& Kovaleva, E.R. (2021). Evaluation of the effectiveness of state financial support for entrepreneurship in the context of the COVID-19 pandemic. Finance, 5, 25-31.

Dezhina, I.G., \& Ponomarev, A.K. (2020). From science to technology: new trends in government policy. Innovations, 10(264), 30-40. doi: 10.26310/2071-3010.2020.264.10.004

Zubarevich, N.V. (2010). Regional development and institutions: Russian specificity. Regional Studies, 2, 3-14.

Zubarevich, N.V. (2020a). Possibilities and limitations of a quantitative assessment of the factors of economic development of Russia's regions. Journal of the New Economic Association, 46, 158-167. doi: $10.31737 / 2221-2264-2020-46-2-8$

Zubarevich, N.V. (2020b). Pandemic and regions: results of January-August 2020. Economic Development of Russia, 27(11), 91-95.

Kuznetsova, O.V. (2020). Vulnerability of the structure of regional economies in crisis conditions. Federalism, 2, 20-38. doi: 10.21686/2073-1051-2020-2-20-38

Kuznetsova, O.V. (2014). Typology of factors of socio-economic development of Russian regions. Moscow University Bulletin. Series 5: Geography, 2, 3-8.

Mau, V.A., Idrisov, G.I., Kuzminov, Ya.I., Radygin, A.D., Sadovnichy, V.A., \& Sinelnikov-Murylev S.G. (2020). Society and Pandemic: Experience and Lessons from COVID-19 Fighting in Russia. Sci. ed. Moscow.

Miles, I., Belousova, V., Chichkanov, N.\& Krayushkina, Zh. (2021). The consequences of the coronavirus crisis for the KIBS sector. Foresight, 1, 6-18. doi: 10.17323/2500-2597.2021.1.6.18

Melnikov, R.M. (2007). Theoretical foundations of regional development regulation: foreign approaches and the possibility of their use in Russian conditions. Moscow: the Russian Academy of Civil Service.

Nigmatulin, R.I., Nigmatulin, B.I., Aganbegyan, A.G., Abramov, M.D., \& Kashin, V.A. (2020). Pandemic 2020: Economic Crisis in Russia. What Needs to be Done. Moscow: GEOTAR-Media, 32. 
Nikolaev, I., Cherepov, V. \& Sobolevskaya, O. (2021). Structural features of the economy and the depth of the economic crisis during the COVID-19 pandemic. Society and Economy, 2, 102-18. doi: 10.31857/S020736760013644-7

Pertsev, A. (2020). Viral federalism: How the epidemic revealed the structure of regional power in Russia. The Carnegie Moscow Center. 07.04.2020. Retrieved from: https://carnegie.ru/commentary/81480 (accessed: 20.06.2021).

Perroux F. The Economy of the twentieth century. Paris, 1961. 512 p.

Polidi, T.D., \& Gershovich, A.Ya. (2021). The impact of coronavirus on the economy of the largest Russian urban agglomerations in 2020. Economic Issues, 5, 145-159. doi: 10.32609/0042-87362021-5-145-159

Romanova, O.A. (2018a). Priorities of industrial policy in Russia in the context of the challenges of the fourth industrial revolution. Part 1. Economy of the Region, 14(2), 420-432. doi: $\underline{10.17059 / 2018-2-7}$

Romanova, O.A. (2018b). Priorities of industrial policy in Russia in the context of the challenges of the fourth industrial revolution. Part 2. Economy of the Region, 14(3), 806-819. doi: 10.17059/2018-2-7

Romanova, O.A. \& Ponomareva, A.O. (2020). Industrial policy: new realities, formation and implementation issues. Economic and Social Changes: Facts, Trends, Forecast, 13(2), 25-40. doi: 10.15838/esc.2020.2.68.2

Seliverstov, V.E., Kravchenko, N.A., Klistorin, V.I., \& Yusupova, A.T. (2021). Russian regions and the federal center in confronting global threats: a year of combating the coronavirus pandemic. Region: Economics and Sociology, 1(109), 3-46. doi: 10.15372/REG20210101

Simachev, Yu.V., \& Kuzyk, M.G. (2021) Interaction of Russian business with science: points of contact and stumbling blocks. Economic Issues, 6, 103-138. doi: 10.32609/0042-8736-2021-6$\underline{103-138}$

Tambovtsev, V.L. (2017) Does industrial policy need theoretical justification? Economic Issues, 5, 29-45. doi: $10.32609 / 0042-8736-2017-5-29-44$

Turgel, I.D., \& Usoltseva, A.A. (2020) An assessment of the degree of openness of state policy in countering COVID-19 in the post-Soviet countries. In: Kleiner G.B. (Ed.) The First International Lviv Forum (October, 2020). Collection of scientific reports. Moscow, 70-172.

Yakishin, Yu.V. (2019) Management of the Structure of the Regional Economy: Theoretical Provisions and Practical Recommendations. St. Petersburg: Ligr.

Bar Am, J., Furstenthal, L., Jorge, F., \& Roth, E. (2020). Innovation in a crisis: Why it is more critical than ever. McKinsey Global Institute. Retrieved from: https://nangs.org/analytics/mckinseyinnovation-in-a-crisis-why-it-is-more-critical-than-ever-june-2020-eng-pdf

Keynes, J.M. (1998). Selected works. Moscow: Economics. 118 p.

Keynes, J.M. (2000). The general theory of employment, interest and money. Anthology of economic classics. Moscow: Ekonov. 375 p.

Krugman, P.R. (1991). Geography and Trade. Cambridge: MIT Press

Lin, J. (2011). New Structural Economics: A Framework for Rethinking Development. World Bank Research Observer, 26, 2, 193-221. Retrieved from: http://hdl.handle.net/10986/13508

Rodrik, D. (2003). In search of prosperity: Analytical narratives on economic growth. Princeton: Princeton University Press, 481.

Rodrik, D. (2013). Structural change, fundamentals, and growth: an overview. Institute for Advanced Study. Revised. doi: 10.2499/9780896292147

\section{Information about the authors}

Olga A. Romanova - Chief Researcher, Doctor of Economics, Professor, Institute of Economics, the Ural Branch of the Russian Academy of Sciences (29, Moskovskaya Street, Yekaterinburg, 620014, Russian Federation); e-mail: romanova.oa@uiec.ru 
Alena O. Ponomareva - Junior Researcher, postgraduate student, Institute of Economics, the Ural Branch of the Russian Academy of Sciences(29, Moskovskaya Street, Yekaterinburg, 620014, Russian Federation); e-mail: ponomareva.ao@uiec.ru

ARTICLE INFO: received July 02, 2021; accepted September 01, 2021

\section{Информация об авторах}

Романова Ольга Александровна - ведущий исследователь, доктор экономических наук, профессор, Институт экономики Уральского отделения Российской академии наук (620014, г. Екатеринбург, ул. Московская, 29); e-mail: romanova.oa@uiec.ru

Пономарёва Алёна Олеговна - младший научный сотрудник, аспирант, Институт экономики Уральского отделения Российской академии наук (620014, г. Екатеринбург, ул. Московская, 29); e-mail: ponomareva.ao@uiec.ru

ИНФОРМАЦИЯ О СТАТЬЕ: дата поступления 2 июля 2021 г.; дата принятия к печати 1 сентября 2021 г. 